\title{
Fatal infectious mononucleosis: a severe complication in the treatment of Crohn's disease with azathioprine
}

E F M Posthuma, R G J Westendorp, A van der Sluys Veer, J C Kluin-Nelemans, Ph M Kluin, C B H W Lamers

\begin{abstract}
A 19 year old man with a history of Crohn's disease treated with azathioprine and prednisone, died after a primary infection with Epstein-Barr virus. He had the characteristics of the virus associated haemophagocytic syndrome, a rare complication of viral infections, which consists of fever, constitutional symptoms, hepatosplenomegaly, liver function and coagulation abnormalities, and hypertriglyceridaemia. Additionally, there was pain, cytopenia, and histiocytic hyperplasia in the bone marrow, spleen, or lymph nodes. This severe complication has been reported previously in renal transplant patients, but not in those with inflammatory bowel disease taking azathioprine. The immunosuppressive therapy may have contributed to this fatal complication of infectious mononucleosis, and this complication should be considered when treating a patient with inflammatory bowel disease with azathioprine.

(Gut 1995; 36: 311-313)
\end{abstract}

Keywords: Crohn's disease, azathioprine, fatal infectious mononucleosis.

\section{Case report}

In 1991, a 19 year old man with a history of Crohn's disease was admitted to hospital because of fever and leukocytopaenia. The diagnosis of Crohn's disease (located in the perianal region and the ileocaecum) had been made in 1988 on clinical, pathological, and radiological features. In 1985, and subsequently during the course of the disease, the patient had iron deficiency anaemia, attributed to gastrointestinal blood loss and poor compliance with iron supplementation. In 1988 an ileocaecal resection was performed. Microscopic examination of the resected specimen showed ulcerative inflammation with features compatible with Crohn's disease. In 1989 the patient was referred to our hospital because of active Crohn's disease that was resistant to therapy with steroids and mesalazine. Eventually, 20 months before his final hospital admission, azathioprine was given with a good clinical response.

He was admitted to hospital in 1991 because of fever which had lasted for about a week. In addition, the patient complained of malaise, fatigue, a sore throat, anorexia, sweats, and headache. His bowel habits had not changed. His medication had consisted of azathioprine
(100 mg daily), prednisone ( $10 \mathrm{mg}$ every other day), and mesalazine (1000 $\mathrm{mg}$ twice daily). He had recently been in contact with someone with infectious mononucleosis.

On examination we saw a sick young man with a temperature of $40 \cdot 0^{\circ} \mathrm{C}$. His blood pressure was $110 / 65 \mathrm{~mm} \mathrm{Hg}$ and his pulse 110 bpm. The sclerae were icteric. There were enlarged lymph nodes in the neck, supraclavicular regions, and axillae but the tonsils were not enlarged. The man had hepatosplenomegaly - the liver was palpable $2 \mathrm{~cm}$ and the spleen $3 \mathrm{~cm}$ below the costal margin.

The laboratory results were as follows: erythrocyte sedimentation rate $22 \mathrm{~mm}$ in the first hour; haemoglobin concentration $4.4 \mathrm{mmol} / \mathrm{l}$; mean corpuscular volume $74 \mathrm{fl}$, reticulocyte fraction $0 \cdot 01$, leukocyte count $1 \cdot 1 \times 10^{9} / 1$ (differentiation $26 \%$ bands, $65 \%$ segmented, $7 \%$ lymphocytes, $2 \%$ monocytes) and thrombocytes $113 \times 10^{9} / 1$; alkaline phosphatase $368 \mathrm{U} / 1$ (normal 15-60 U/l), aspartate aminotransferase $70 \mathrm{U} / 1$ (normal 2-15 U/1), lactate dehydrogenase $580 \mathrm{U} / 1$ (normal $<160 \mathrm{U} / \mathrm{l}$ ), $\gamma$ glutamyltransferase $105 \mathrm{U} / 1$ (normal 6-28 $\mathrm{U} / \mathrm{l}$ ), total bilirubin $68 \mu \mathrm{mol} / 1$ (normal $<17$ $\mu \mathrm{mol} / \mathrm{l}$ ), albumin $24 \mathrm{~g} / \mathrm{l}$ (normal $>40 \mathrm{~g} / \mathrm{l}$ ), ferritin $8173 \mu \mathrm{g} / \mathrm{l}$ (normal 35-260 $\mu \mathrm{g} / \mathrm{l}$ ), and triglycerides $3.11 \mathrm{mmol} / \mathrm{l}$ (normal $0.8-1.94$ $\mathrm{mmol} / \mathrm{l})$. The plasma fibrinogen was $0.8 \mathrm{~g} / \mathrm{l}$ (normal $1 \cdot 7-3 \cdot 7 \mathrm{~g} / 1$ ), activated partial thromboplastin time $49 \mathrm{~s}$ (normal 25-36 s) and the prothrombine time $33 \mathrm{~s}$ (normal 12-15 s).

The Mancini radial immunodiffusion for IgG was $20.4 \mathrm{~g} / 1$ (normal 8-18 g/l), for IgM 4.6 $\mathrm{g} / 1$ (normal $0.6-2.5 \mathrm{~g} / \mathrm{l}$ ), and for IgA $3.9 \mathrm{~g} / 1$ (normal 0.9-4.5 g/l). (In 1990 the values were IgG $12.8 \mathrm{~g} / \mathrm{l}, \operatorname{IgM} 1.4 \mathrm{~g} / \mathrm{l}$, and IgA $2.8 \mathrm{~g} / \mathrm{l}$.) Monoclonal components were not detectable. A monospot test was positive. The titre of IgM anti-Epstein-Barr viral capsid antigen (EBVVCA) antibodies was 1:4096; IgG anti-EBVVCA $1: 2048$, antibodies against early antigen (EBV-EA), and nuclear antigen (EBV-NA) were negative. HIV serology and immunoblotting showed no indication of infection.

Ultrasound examination of the abdomen showed hepatosplenomegaly and lymphadenopathy in the portal region. A chest $x$ ray at admission to hospital was normal, but bilateral hilar lymphadenopathy developed later. A bone marrow aspirate showed hypercellularity with an increase of plasma cells and atypical lymphoid cells; a pronounced megakaryocytic hyperplasia was seen with a left shift in maturation. Granulopoiesis was diminished and left shifted. Immunofluorescence 


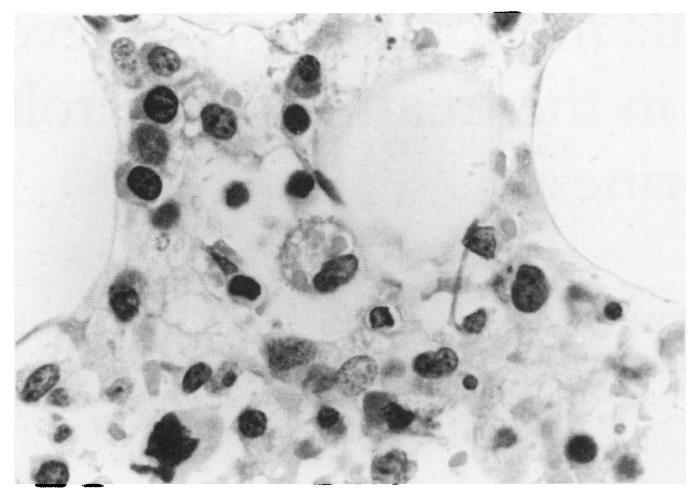

Bone marrow biopsy specimen: one macrophage with erythrophagocytosis is shown in the central area (original magnification $\times 400$ ).

examination of the plasma cells and lymphoid cells was compatible with a polyclonal reaction. A bone marrow biopsy showed infiltration of plasma cells, an increase of macrophages, phagocytosed red blood cells, and erythroid hyperplasia (Figure).

The diagnosis of a severe Epstein-Barr virus infection in a patient with immunosuppressive therapy was made. The azathioprine was stopped immediately on hospital admission. The drug may have induced the pancytopenia, although in the months before admission on the same dose of azathioprine, leukocyte and thrombocyte values were within the normal range. Prednisone had to be continued at an increased dose because of potential adrenal insufficiency. The Table shows medication and laboratory parameters before and during admission.

Specific therapy consisted of acyclovir, $\alpha$ interferon, immunoglobulins, and plasmapheresis. Despite this, progressive pancytopenia, renal and respiratory failure, cholestatic jaundice, hepatic failure, and red blood cell fragmentation developed. Eventually, 18 days after hospital admission, the patient died of an irreversible multiple organ failure, complicated in the final stage by a sepsis with Escherichia coli. Post mortem examination was not permitted.

\section{Discussion}

Infectious mononucleosis caused by EpsteinBarr virus is usually a benign disease.

Laboratory parameters and medication before and during Epstein-Barr virus infection

\begin{tabular}{|c|c|c|c|c|c|}
\hline \multirow[b]{2}{*}{ Laboratory parameters } & \multicolumn{5}{|l|}{ Values } \\
\hline & Normal & $\begin{array}{l}\text { Before } \\
\text { infection }\end{array}$ & $\begin{array}{l}\text { On } \\
\text { admission }\end{array}$ & Week 1 & Week 3 \\
\hline Haemoglobin $(\mathrm{mmol} / \mathrm{l})$ & $8 \cdot 5-11 \cdot 0$ & $6 \cdot 2$ & $4 \cdot 4$ & $5 \cdot 1^{\star}$ & $7 \cdot 1^{\star}$ \\
\hline Mixed cell volume (f) & $80-100$ & 68 & 74 & 78 & - \\
\hline Leukocytes $\left(10^{9} / 1\right)$ & $4 \cdot 5-11 \cdot 0$ & $4 \cdot 6$ & $1 \cdot 1$ & $0 \cdot 7$ & $3 \cdot 1$ \\
\hline Thrombocytes $\left(10^{9} /\right)$ & $150-350$ & 606 & 113 & 62 & 15 \\
\hline Bilirubin, total $(\mu \mathrm{mol} / \mathrm{l})$ & $<17$ & 3 & 68 & 208 & 409 \\
\hline Creatinin $(\mu \mathrm{mol} / \mathrm{l})$ & $70-133$ & 78 & 88 & 186 & 410 \\
\hline Ferritin $(\mu g / 1)$ & $35-260$ & 15 & 8173 & - & $\overline{-}$ \\
\hline Triglyceride $(\mathrm{mmol} / \mathrm{l})$ & $0.80-1.94$ & - & $2 \cdot 11$ & - & $3 \cdot 11$ \\
\hline $\begin{array}{l}\text { Treatment } \\
\text { Azathioprine }\end{array}$ & & + & - & - & - \\
\hline Mesalazine & & + & - & - & - \\
\hline Prednisone & & + & + & + & + \\
\hline Acyclovir & & - & - & + & + \\
\hline Plasmapheresis & & - & - & + & + \\
\hline Gammaglobulin & & - & - & + & + \\
\hline Interferon & & - & - & + & + \\
\hline
\end{tabular}

^After transfusion of red blood cells.
Severe complications such as splenic rupture, encephalitis, Guillain-Barré syndrome, seizures, myocarditis, pericarditis, hepatitis, airway obstruction, cytopenias, and immune deficiencies are seen in $1 \%$ of all patients. ${ }^{1-3}$ Fatalities are even more rare. Penman, ${ }^{4}$ who reviewed all published reports in 1970, could attribute only 20 deaths to infectious mononucleosis. The most frequent causes of death were neurologic complications, respiratory failure, splenic rupture, and secondary infection.

At the end of the 1970s two new syndromes related to fatal infectious mononucleosis were reported. ${ }^{56}$ In the first, Risdall et $a l^{5}$ described a clinicopathological syndrome associated with a viral infection (including Epstein-Barr virus) in 19 patients whose bone marrow smears showed histiocytic hyperplasia with prominent haemophagocytosis. This so called virus associated haemophagocytic syndrome (VAHS) is characterised by high fever, constitutional symptoms, abnormal liver function tests, and a coagulopathy that is more severe than that expected on the basis of the abnormal liver function tests and cytopenia. Hepatosplenomegaly, lymphadenopathy, bilateral pulmonary infiltrates, and skin rash are often present. Subsequently, hypertriglyceridaemia and hyperferritenaemia were reported in relation to VAHS. ${ }^{7}$

Patients with fatal infectious mononucleosis frequently have VAHS. Moreover this syndrome has been associated with patients on immunosuppressive therapy. Fourteen of the 19 patients originally described had been on immunosuppressive therapy (azathioprine and prednisone). Thirteen were renal transplant patients, while one suffered from systemic lupus erythematosus. ${ }^{5}$ Opportunistic infections and haemorrhage are the major causes of death. ${ }^{8}$ Reiner and Spivak reported 23 patients with the same syndrome, related not only to viral but also to bacterial infections. Again, most of them were immunocompromised. ${ }^{9}$

The second syndrome in which fatal mononucleosis can occur is the X-linked lymphoproliferative (XLP) syndrome. It is characterised by an impaired immune response to Epstein-Barr virus manifested by fatal infectious mononucleosis, malignant lymphoma, or gammaglobulinaemia. ${ }^{1-3681011}$ The clinicopathological features of both VAHS and XLP are similar, although patients with XLP are, by definition, of the male sex, have a median age of 2.5 years (versus 13 years in fatal infectious mononucleosis not related to XLP), and have maternally related male relatives with other phenotypes of XLP. ${ }^{12}$ Males affected with the XLP syndrome can be detected before Epstein-Barr virus infection using linkage analysis with DNA probes, antibody response tests with bacteriophage $\mathrm{X} 174$ challenge, and determination of immunoglobulin class and subclass levels (IgG, IgG1, or IgG3 deficiency; raised IgA or IgM). ${ }^{13} 14$ During Epstein-Barr virus infection patients with XLP syndrome show a deficient antibody response to EpsteinBarr virus antigens, especially to EBV-NA. ${ }^{15}$

Our patient met all the criteria - clinical, laboratory, and histopathological - of VAHS 
mentioned above. Both the absence of affected relatives and the relatively greater age of the patient argue against the XLP syndrome. In addition, the normal immunoglobulins concentrations before the Epstein-Barr virus infection plead against XLP syndrome. ${ }^{14}$ In accordance with the published reports, it is probable that the azathioprine treatment played a part in his illness. ${ }^{59}$ To our knowledge, our patient is the first described with a fatal Epstein-Barr virus infection in the setting of immunosuppressive therapy given for an inflammatory bowel disease.

Although it is unusual, one may expect an increase of fatal infectious mononucleosis because of the more frequent use of immunosuppressive therapy for inflammatory bowel diseases. ${ }^{16}$ This applies especially to young patients who have a bigger chance of a primary Epstein-Barr virus infection. We think that this rare but severe complication of treatment with azathioprine is a warning against a too liberal use of azathioprine in the management of inflammatory bowel disease.

1 Straus SE, Cohen JI, Tosato G, Meier J. Epstein-Barr virus infections: Biology, pathogenesis and management. Ann Intern Med 1993; 118: 45-58.

2 Foerster J. Infectious mononucleosis. In: Lee GR, Bithel TC, Foerster J, Athens JW, Lukens JN, eds. Winthrobe's clinical hematology. 9th ed. Lea and Febiger: Philadelphia, 1993: 1650-75

3 Tomkinson BE, Sullivan JL. Infectious mononucleosis and other Epstein-Barr virus associated infections. In:
Hoffman R, Benz EJ, Shattil SJ, Furie B, Cohen HJ, eds. Haematology: basic principles and practice. New York: Haematology: basic principles and pract

4 Penman HG. Fatal infectious mononucleosis: a critical review. F Clin Pathol 1970; 23: 765-71.

5 Risdall RJ, McKenna RW, Nesbit ME, Krivit W, Balfour $\mathrm{HH}$, Simmons RL, et al. Virus-associated hemophagocytic syndrome. A benign histiocytic proliferation distinct from malignant histiocytosis. Cancer 1979; 44: 993-1002.

6 Purtilo DT. Hypothesis: pathogenesis and phenotypes of an $\mathrm{X}$-linked lymphoproliferative syndrome. Lancet 1976; ii: $882-5$.

7 Henter J, Elinder G, Ost A. Diagnostic guidelines for hemophagocytic lymphohistiocytosis. Semin Oncol 1991; 18: 29-33.

8 Mroczek EC, Weisenburger DD, Lipscomb-Grierson HI Markin R, Purtilo DT. Fatal infectious mononucleosis and virus-associated hemophagocytic syndrome. Arch Pathol Lab Med 1987; 111: 530-35.

9 Reiner AP, Spivak J. Hematophagic histiocytosis. A report of 23 patients and a review of the literature. Medicine 1988; 67 (6): 369-88

10 Purtilo DT, Szymanski I, Bhawan J, Yang JPS, Hutt LM, Boto W, et al. Epstein-Barr virus infections in the Xlinked recessive lymphoproliferative syndrome. Lancet 1978; i: 798-801.

11 Purtilo DT. X-linked lymphoproliferative disease (XLP) as a model of Epstein-Barr virus-induced immunopathology. Springer Semin Immunopathol 1991; 13: 181-97.

12 Purtilo DT, Strobach RS, Okano M, Davis JR. Biology of disease. Epstein-Barr virus-associated lymphoproliferative disease. Epstein-Barr virus-associated
disorders. Lab Invest 1992; 67: 5-23.

13 Purtilo DT, Grierson HL, Ochs H, Skare J. Detection of X-linked lymphoproliferative disease using molecular and immunovirologic markers. $A m$ f Med 1989; 87: 421-4.

14 Grierson HL, Skare J, Hawk J, Pauza M, Purtilo DT Immunoglobulin class and subclass deficiencies prior to Epstein-Barr virus infection in males with $\mathrm{X}$-linked lymphoproliferative disease. Am $\mathcal{F}$ Med Gen 1991; 40: 294-7.

15 Sakamoto K, Freed HJ, Purtilo DT. Antibody response to Epstein-Barr virus virus in families with the X-linked lymphoproliferative syndrome. F Immunol 1980; 125: 921-5.

16 Hanauer SB. Inflammatory bowel disease revisited: newer drugs. Scand $\mathcal{f}$ Gastroenterol 1990; 25 (suppl 175): drugs. 